\title{
Selection of low swelling materials for protein adsorption from white wines
}

\author{
Miguel R. Sarmento ${ }^{1}$, Jorge C. Oliveira ${ }^{2 *} \&$ Roger B. Boulton ${ }^{3}$ \\ 1 Escola Superior de Biotecnologia, UCP, R. Dr António B. Almeida, Porto, Portugal \\ 2 Inter-University Institute of Macau, NAPE, Lot 18, Rua de Londres, Edf. Tak Ip \#P, Macau \\ 3 Department of Viticulture and Enology, University of California, Davis CA 95616, USA
}

\begin{abstract}
Summary The protein adsorption capacity of different materials was evaluated to assess their potential efficacy as alternative adsorbents for the removal of proteins from wines, with the purpose of finding suitable low-swelling materials that could be used in a percolated bed. The adsorbents tested were thermally treated sodium bentonite, low-swelling adsorbing clays, ion exchange resins and other protein adsorbents (silica gel, hydroxyapatite and alumina). The materials were evaluated by analysing both the capacity to stabilize untreated white wines, according to a heat test, and by characterizing the adsorption isotherms of bovine serum albumin (BSA) in a model wine (water, ethanol and K-bitartrate). Breakthrough curves in a packed bed were determined experimentally for some materials, showing the influence of the adsorption isotherm shape. Some ionexchange resins showed a favourable behaviour and have good potential as alternative adsorbents.
\end{abstract}

Keywords Bentonite, percolated beds, sorption isotherms, wine stability.

\section{Introduction}

The development of protein hazes is one of the most common physical instabilities in white and rosé wines (Boulton, 1980). Wines can be clear when bottled but later develop cloudiness owing to protein instability resulting from changes in storage conditions. Wine proteins show great variability. The actual protein profile of a wine is as a result of a complex combination of factors that include climate, soil, cultivar, cultural practices, growth conditions and enological practices. The total protein content varies greatly, with reported values ranging from $14.2 \mathrm{mgL}^{-1}$ to 275 $\mathrm{mg} / \mathrm{L}$. Reported isoelectric points $(\mathrm{pI})$ range from 3.1 to 9.2 (Moyo \& Addeo, 1989) and molecular weights vary from 11 to $160 \mathrm{kDa}$, although most

*Correspondent: Department of Food Science and Technology, University College Cork, Cork, Ireland. e-mail: JMFCO@hotmail.com proteins are smaller than $70 \mathrm{kDa}$ (Moretti \& Berg, 1965; Bayley \& Berg, 1967; Somers \& Ziemelis, 1973; Hsu \& Heatherbell, 1987; Lamikanra \& Inyang, 1988; Murphey et al., 1989).

Protein instability, i.e. its precipitation, depends not only on the protein itself but on the interactions with the medium. A certain protein can be stable in a wine and unstable in another, due to a complex matrix of factors, such as $\mathrm{pH}$, ionic strength, ethanol concentration and temperature (Lehninger, 1981). Interactions with matrix components, such as phenolics (Yokotsuka et al., 1983), tannins (Mesrob et al., 1983) and cations, mainly copper (Kean \& Marsh, 1956), are also influential.

A comprehensive understanding of the different wine protein profiles and how these relate to instability problems under the influence of the different factors listed above is unfortunately not yet available. 
The fact that proteins are negatively charged above the $\mathrm{pI}$ and positively below has been used to solve the instability problems. Sodium bentonite is mainly used to remove all wine proteins by means of cation exchange: since the $\mathrm{pI}$ of most wine proteins is above the average wine $\mathrm{pH}$, this agent acts as an adsorbent. Sodium bentonite is a very efficient material for this purpose, mainly because of its colloidal nature that stems from the ability to separate into extremely thin flakes upon agitation in water for a period of time. This results in a very large surface area that has an overall negative surface charge, due to inter-lattice substitutions (Siddiqui, 1968). Bentonite does not affect flavour or taste and has also been attributed the property of removing oxidative enzymes when used before or during fermentation, thereby minimizing browning problems.

However, sodium bentonite particles swell significantly when hydrated and its separation from the wine is not an efficient process. Diatomaceous earth must be added as filtering aid to prevent clogging. The resulting filter cake is discarded into the environment, being one of the major sources of effluents in wineries. It has a low density, taking some days to settle in riverbeds, and the diatomaceous earth contains silica dust and may be considered potentially harmful. This process also causes significant losses of wine, captured in the slurry (local wineries estimate over $10 \%$ losses).

An alternative to this conventional process would be the use of percolated beds (that is, packed or fluidized beds of adsorbent in a column, through which the wine would flow while losing the proteins that would remain in the column, adsorbed). Such a process would allow for regeneration of the adsorbent, thereby reducing both residues and operating costs. This type of system has found many applications in several fields, namely in the chemical and pharmaceutical industries. Increasing applications of percolated bed adsorption are also being found in environmental engineering for removing contaminants from effluents.

This type of process requires an adsorbent of a constant size and therefore the swelling sodium bentonite cannot be used. Looking for an alternative adsorbing material implies screening materials that have the following characteristics: (a) suitable adsorption capacity of wine proteins; (b) low swelling and adequate particle size distribution; (c) possibility to be regenerated, which implies physical stability.

Given the previous discussion, it is evident that the choice of an adequate material for developing a percolated bed system for wine protein adsorption requires the knowledge of: (a) the protein adsorption isotherm, indicating the material's adsorption capacity; (b) the capacity to actually stabilize wines, meaning that enough removal of fractions causing instability was achieved; and (c) the breakthrough curve in the packed bed, i.e. the evolution of the protein concentration at the column's outlet, indicating the point when the bed becomes saturated and must be regenerated.

In the case of protein adsorption by porous materials, the breakthrough curve is influenced by the kinetics of mass transfer that are related to the characteristics of the matrix, namely the size of the pores and the size of the particle. In particular, the adsorption capacity is drastically decreased if pores are so small that proteins cannot enter them, limiting adsorption to the outside surface.

Couture (1985) studied the use of bentonite as a sealing agent in nuclear waste repositories and showed that reaction with water vapour at $150-250{ }^{\circ} \mathrm{C}$ drastically decreases the swelling ability of bentonite without loss of exchangeable ions, and therefore this might be a suitable material for percolated bed adsorption. However, it is shown here that this treatment severely reduces the protein adsorption capacity in wine. Other options identified were non-swelling clays, macroporous ion-exchange resins and other protein adsorbers (silica gel, hydroxyapatite and alumina).

\section{Materials and methods}

\section{Model solution}

In order to quantify the adsorption capacity of the different materials, the adsorption isotherm at room temperature of Bovine Serum Albumin (BSA), fraction V (Merck KGaA, Germany) was determined, using a model wine solution, made of an ethanol solution with K-bitartrate (potassium hydrogen tartrate) and BSA (Blade \& Boulton, 1988). This model wine provides the relevant con- 
ditions for the protein adsorption process: $\mathrm{pH}$, dielectric constant and ionic strength. BSA is a water soluble protein that acts as a protein carrier (Loomis, 1979). It is a large molecule (molecular weight (MW) $66 \mathrm{kDa}$ ), with a pI of 4.3-4.6, which is in the range of most wine proteins. Since it is a larger molecule than most wine proteins, it leads to conservative results; that is, materials that adsorb it are bound to be efficient with grape or wine proteins whereas the reverse may not be true.

The model wine was prepared with $12 \%(\mathrm{v} / \mathrm{v})$ ethanol and $2 \mathrm{gL}^{-1}$ of potassium hydrogen tartrate in distilled water. The solution had a final $\mathrm{pH}$ of 3.72 .

\section{Adsorbents}

The materials selected for screening as potential wine protein adsorbents are listed in Table 1. Vapour-treated bentonite was obtained by holding small cylindrical pressure resistant recipients with $0.15 \mathrm{~g}$ water $\mathrm{g}^{-1}$ bentonite for 1 week at $250{ }^{\circ} \mathrm{C}$
(Couture, 1985). Normal sodium bentonite was also used for comparison.

\section{Adsorption isotherms}

To ensure previous hydration, different amounts of each adsorbent were mixed with $150 \mathrm{~mL}$ of protein free model solution and agitated for $2 \mathrm{~h}$ using magnetic stirrers (Multipoint HP15, Variomag, Germany) in a water bath at $20{ }^{\circ} \mathrm{C}$. One hundred and fifty $\mathrm{ml}$ of a 1000 p.p.m. BSA in model wine solution were then added to give a final concentration of 500 p.p.m., followed by agitation at $20{ }^{\circ} \mathrm{C}$ until equilibrium. Each sample was then filtered through $0.45-\mu \mathrm{m}$ filters and the BSA concentration measured by spectrophotometry at $280 \mathrm{~nm}$ against a calibration curve. In some cases, a previous centrifugation at 5000 r.p.m for $5 \mathrm{~min}$ was needed to decrease membrane fouling. In the case of the resins, pendular magnetic stirrers had to be used to prevent crushing of the beads between the stirrer and the walls of the flask.

Table 1 Characteristics of the adsorbents tested (indicated by the suppliers)

\begin{tabular}{|c|c|c|c|c|c|c|}
\hline Material & Matrix & $\begin{array}{l}\text { Ionic capacity } \\
\text { (meq } \mathbf{~ g}^{-1} \text { ) }\end{array}$ & $\begin{array}{l}\text { Pore size } \\
\text { (A) }\end{array}$ & $\begin{array}{l}\text { Particle size } \\
(\mu \mathrm{m})\end{array}$ & $\begin{array}{l}\text { lonizable } \\
\text { group }\end{array}$ & Supplier \\
\hline Swelling clays & Alumino silicate & & & & & \\
\hline Smectite & & - & variable & $<50$ & - & (1) \\
\hline Saponite & & - & variable & $<50$ & - & (1) \\
\hline Hectorite & & 440 & variable & $<50$ & - & (1) \\
\hline Bentonite & & 764 & variable & $<50$ & - & (2) \\
\hline Low-swelling clays & Alumino silicate & & & & & \\
\hline Attapulgite & & 195 & & $<50$ & - & (1) \\
\hline Kaolinite & & 33 & 4.5 & $<50$ & - & (1) \\
\hline \multicolumn{7}{|l|}{ lon-exchange resins } \\
\hline Macro-prep 50S & Acrylic & 160 & 1000 & $35-60$ & Sulphonic & (2) \\
\hline Streamline SP & Agarose & 142 & - & $100-300$ & Sulphonic & (4) \\
\hline Spherosil LS & Porous Silica & 400 & 1000 & $100-300$ & Sulphonic & (5) \\
\hline AG MP 50 & $\mathrm{SDB}^{*}$ & 1500 & - & $100-300$ & Sulphonic & (3) \\
\hline Amberlite 200 & $\mathrm{SDB}^{*}$ & 1700 & - & $300-900$ & Sulphonic & (6) \\
\hline Dowex MSC1 & $\mathrm{SDB}^{*}$ & 1700 & - & $300-900$ & Sulphonic & (7) \\
\hline \multicolumn{7}{|l|}{ Other materials } \\
\hline \multirow[t]{2}{*}{ Spherosil ХOB15 } & Porous silica & - & 1000 & $100-300$ & - & (5) \\
\hline & & - & non-porous & - & - & (8) \\
\hline Alumina & - & - & non-porous & - & - & (8) \\
\hline Hydroxyapatite & - & - & non-porous & 0.002 & - & (9) \\
\hline Silica gel & - & & & & & \\
\hline
\end{tabular}

*SDB: cross-linked styrene divinylbenzene. Suppliers: (1) Source clays, University of Missouri, USA; (2) Georgia Kaolin CO, USA; (3) BioRad Laboratories, USA; (4) Pharmacia BioProcess Tech. AB, Sweden; (5) Institut Merieux, Marcy I'Etoile, France; (6) Rohm \& Haas Cia, USA; (7) Dow Chemical Comp., USA; (8) Sigma, Chemical Company, USA; (9) Proenol, Lda, VN Gaia, Portugal. 


\section{Heat test}

The capacity of the different materials to stabilize real wines was assessed by performing a heat test in non-stabilized wines, after mixture with the different adsorbents. This test is based on causing the precipitation of the proteins as a result of their heat denaturation and is the most commonly used in industrial practice. The adsorbents were placed in $300-\mathrm{mL}$ wine samples, following the same procedure used for the adsorption isotherms. All adsorbents were added in excess, at a concentration of $10 \mathrm{gL}^{-1}$. Wine was then held for $2 \mathrm{~h}$ at $90^{\circ} \mathrm{C}$, followed by $2 \mathrm{~h}$ at $4{ }^{\circ} \mathrm{C}$ and final equilibration to room temperature. Turbidity was then measured using a hazemeter (Haffmans model vos 400, Germany) and was expressed in EBC units.

\section{Breakthrough curves}

Materials that had shown different types of adsorption isotherms were used for determining breakthrough curves of the model wine solution through a packed bed of adsorbent in order to show the influence of the shape of the adsorption isotherm on the efficiency of a percolated bed adsorption system. A laboratory-scale column (economy columns, Spectra Physics, USA) with a $10-\mathrm{mm}$ internal diameter and 10-cm length was fully packed with adsorbent. Flow circulated downwards to maintain a fixed bed, using a Gilson model 3 peristaltic pump, at a flow rate of $3 \mathrm{~mL} \mathrm{~min}^{-1}$. The BSA concentration, initially at $500 \mathrm{mgL}^{-1}$, was measured on-line at the column outlet using a $10-\mathrm{mm}$ path flow cell in a UV/VIS spectrophotometer (Unicam 8620, Phillips, Netherlands), at $280 \mathrm{~nm}$. Data acquisition was performed by a PC (IBM 286) linked to the spectrophotometer.

\section{Results and discussion}

\section{Heat test}

Some materials were not able to stabilize the wine samples, according to the results of the heat test shown in Table 2. These were macroporous
Table 2 Heat test results of wines treated with the adsorbents tested (average of two replicates for four wines).

\begin{tabular}{|c|c|c|c|}
\hline \multirow[b]{2}{*}{ Adsorbents } & \multicolumn{2}{|c|}{ Turbidity (EBC units) } & \multirow{2}{*}{$\begin{array}{l}\text { Visual } \\
\text { appearance } \\
\text { after } \\
\text { testing }\end{array}$} \\
\hline & $\begin{array}{l}\text { Before } \\
\text { testing }\end{array}$ & $\begin{array}{l}\text { After } \\
\text { testing }\end{array}$ & \\
\hline Control & 0.1 & 10.3 & turbid \\
\hline Bentonite & 0.1 & 0.7 & clear \\
\hline \multicolumn{4}{|l|}{ Swelling clays } \\
\hline Smectite & 0.2 & 0.7 & clear \\
\hline Saponite & 0.3 & 0.8 & clear \\
\hline Hectorite & 0.2 & 1.1 & clear \\
\hline \multicolumn{4}{|l|}{ Low-swelling clays } \\
\hline Vapour-treated bentonite & 0.1 & 0.9 & clear \\
\hline Attapulgite & 0.2 & 1.0 & clear \\
\hline Kaolinite & 0.1 & 0.9 & clear \\
\hline \multicolumn{4}{|l|}{ Ion exchange resins } \\
\hline Macro-prep 50S & 0.1 & 0.7 & clear \\
\hline Streamline SP & 0.2 & 0.8 & clear \\
\hline S Spherosil LS & 0.1 & 0.7 & clear \\
\hline AG MP 50 & 0.1 & 10.1 & turbid \\
\hline Amberlite 200 & 0.1 & 10.2 & turbid \\
\hline Dowex $\mathrm{MsC1}$ & 0.1 & 10.3 & turbid \\
\hline \multicolumn{4}{|l|}{ Other materials } \\
\hline Spherosil XOB15 & 0.1 & 1.1 & clear \\
\hline Alumina & 0.3 & 10.1 & turbid \\
\hline Hydroxyapatite & 0.4 & 2.1 & clear \\
\hline Silica gel & 0.5 & 1.1 & clear \\
\hline
\end{tabular}


cation exchange resins of cross-linked styrene-divinylbenzene (AG ${ }^{\circledR}$ MP50, Amberlite ${ }^{\circledR}$ 200 and Dowex $^{\oplus} \mathrm{MsCl}$ ) and alumina. All other materials yielded comparable results, as good as normal sodium bentonite.

\section{Adsorption isotherms}

Regarding adsorption capacity, measured in terms of the BSA adsorption isotherm, no material tested had a higher capacity than normal sodium bentonite. Figure 1 shows the isotherms of swelling clays, where it can be seen that smectite also has a high adsorption capacity, while hectorite and saponite showed a considerably lower capacity. The macroporous ion exchange resins, Macro-Prep ${ }^{\circledR} 50 \mathrm{~S}, \quad \mathrm{~S}$ Spherosil ${ }^{\circledR} \mathrm{LS}$ and Streamline ${ }^{\mathrm{TM}} \mathrm{SP}$, also have similar, convex, isotherms (Fig. 2). Low-swelling materials showed three different types of isotherms (Fig. 3): concave (Spherosil ${ }^{\circledR} \mathrm{XOB} 15$, alumina, hydroxyapatite and kaolinite), approximately linear (vapour treated bentonite and attapulgite) and convex (silica gel).

The convex shape has a more practical interest. It can be shown by mathematical modelling that a concave shape corresponds to an early saturated breakthrough curve while the convex shape corresponds to an S-like breakthrough curve. This can be seen in the experimental results obtained for the breakthrough curves of BSA in Spherosil $^{\circledR}$ XOB15 and in Macro-Prep ${ }^{\circledR}$ 50S, shown in Fig. 4. The Spherosil ${ }^{\mathrm{TM}}$ XOB15 bed shows a much more rapid saturation. Due to this fact, convex shapes are known in percolation theory as favourable, while concave are named unfavourable.

The convex isotherms of the swelling clays, silica gel and the macroporous ion exchangers also show a maximum adsorption capacity. These types of curves are usually well described by the Langmuir equation and are known as type $\mathrm{I}$ in the classification of Brunnauer, Deming and Teller (Terence, 1990). They are characteristic of pore filling, with the amount adsorbed being limited by the pore volume only. This is usual in the adsorption of large molecules, which is the case of proteins, since the binding forces from the surface-active sites are negligible beyond the first layer dimension. For Langmuir-type curves, two parameters are used to characterize the isotherm: the capacity, i.e. the maximum amount of adsorbed material, and the constant, which is related to the slope of the early part of the curve: the lower the constant, the higher the slope and the sooner the maximum capacity is achieved. Langmuir's capacity and constant for materials with convex adsorption isotherms are shown in Table 3. The reason for all ion-exchange resins showing a similar pattern can be linked to the fact that they all have sulphonic acid as the ionizable group. However, they have different capacities, and this may be due to different densities of ionizable groups or to different pore volumes.

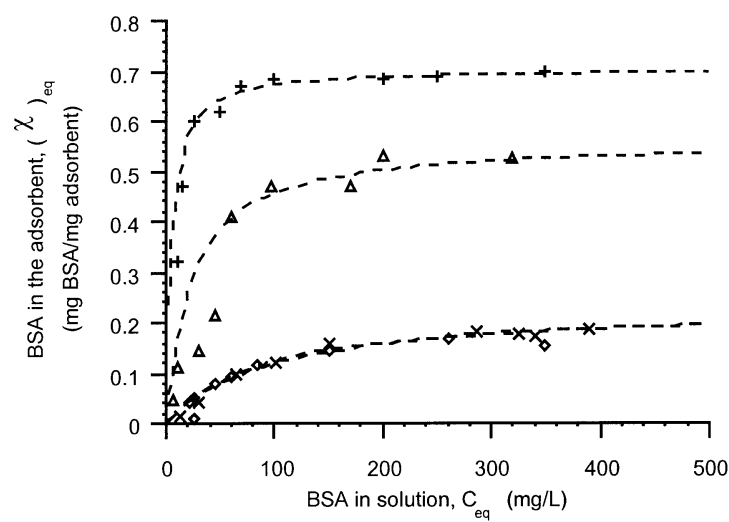

Figure 1 Adsorption isotherms of BSA in swelling clays ( + bentonite, $\triangle$ smectite, $\diamond$ hectorite, $X$ saponite). The dotted lines are the fits of the experimental data to the Langmuir equation.

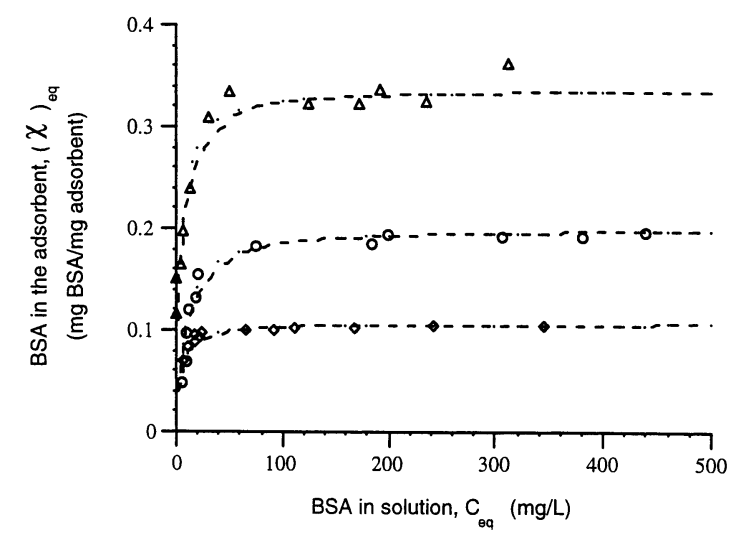

Figure 2 Adsorption isotherms of BSA in macroporous ion exchange materials $\left(\triangle\right.$ Streamline ${ }^{\text {TMSP}}$; $\bigcirc$ Macroprep ${ }^{\otimes} 50 \mathrm{~S} ; \diamond \mathrm{S}$ Spherosil $\left.{ }^{\otimes} \mathrm{LS}\right)$. The dotted lines are the fits of the experimental data to the Langmuir equation. 
(a)

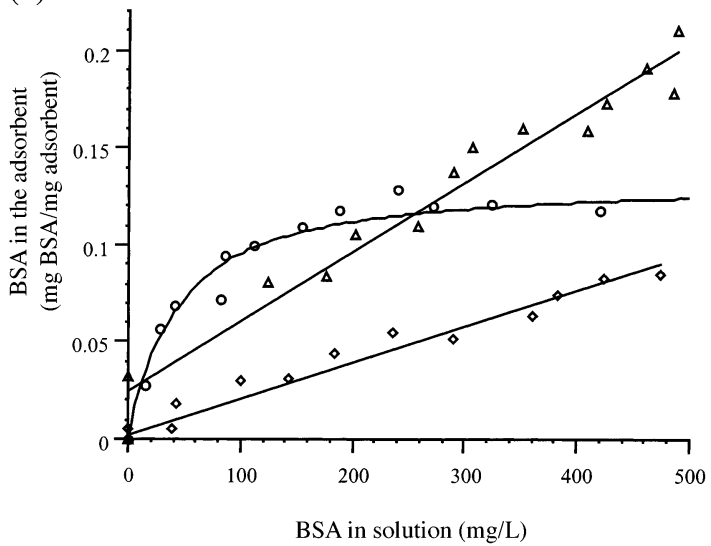

(b)

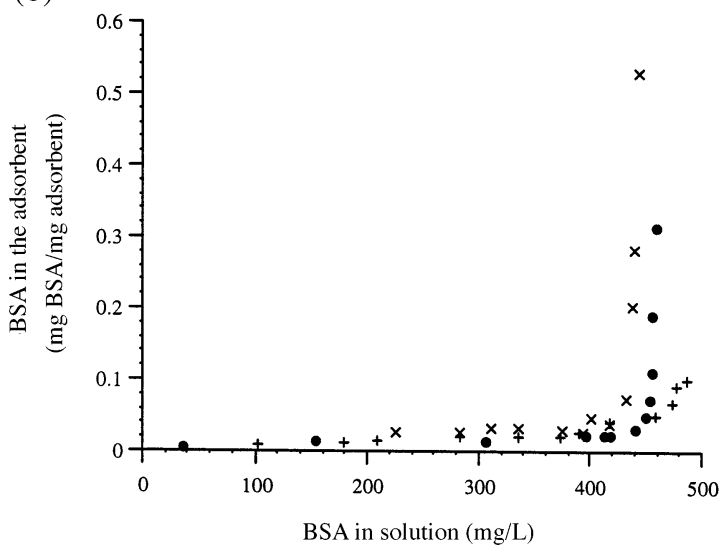

Figure 3 Adsorption isotherms of BSA in low-swelling adsorbents. (a) convex and linear shapes ( $\triangle$ attapulgite; $\bigcirc$ silica gel; $\diamond$ vapour-treated bentonite); (b) concave shapes (+ hydroxyapatite; $\times$ kaolinite; $\bigcirc$ spherosilXOB15). The solid lines are the fits of the experimental data to a straight line or the Langmuir equation.

The concave shape is named type III in Brunnauer, Deming and Teller's classification. This corresponds to weak adsorbent-adsorbate interactions. It can therefore be suggested that kaolinite shows this behaviour due to a structure with rare isomorphous substitutions in its lattice. Base exchange capacity is attributed to relatively small numbers of broken bonds on the edges of fragments. The units are kept together and the mineral does not disintegrate to very small particles. The area of the edges of the sheets is small (Grim, 1939; Siddiqui, 1968) and this would explain the weak interaction observed.

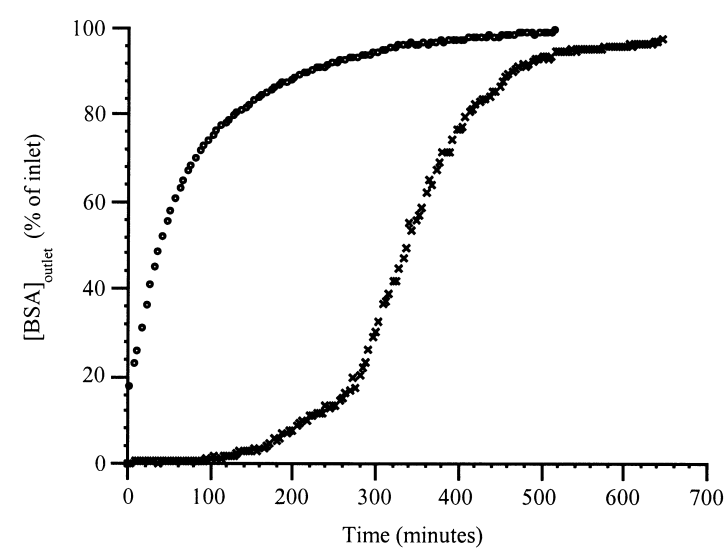

Figure 4 Breakthrough curves of BSA in packed beds of Macro-prep ${ }^{\oplus 0 S}(\bigcirc)$ and of Spherosil ${ }^{\oplus}$ XOB15 $(\times)$. Flow rate $=3.0 \mathrm{ml} \mathrm{min}{ }^{-1}$; column internal diameter: $1.0 \mathrm{~cm}$; bed height: $10 \mathrm{~cm}$.
Attapulgite and vapour-treated bentonite have shown linear isotherms, named type II in Brunnauer, Deming and Teller's classification, that is typical of non-porous and mesoporous structures. In the case of attapulgite, this material has a fibrous structure. The accessibility to the active sites is limited by channels of a $5.5 \times 6.5$ $\AA$ free cross-section (Hendricks, 1942; Siddiqui, 1968), not large enough to admit protein molecules. The fact that attapulgite does not swell therefore limits its adsorption capacity to the outer surface and hence the linear isotherm. A similar reason may be behind the drastic capaci-

Table 3 Langmuir constants of the materials with type I adsorption isotherms

\begin{tabular}{|c|c|c|}
\hline Material & $\begin{array}{l}\text { Capacity, } \chi_{\max } \\
\left(\mathbf{m g m g}^{-1}\right)\end{array}$ & $\begin{array}{l}\text { Langmuir constant, } \mathrm{K}_{\mathrm{L}} \\
\left(\mathrm{mgL}^{-1}\right)\end{array}$ \\
\hline Na-bentonite & 0.702 & 2.19 \\
\hline Smectite & 0.560 & 22.7 \\
\hline Saponite & 0.233 & 84.2 \\
\hline Hectorite & 0.228 & 96.0 \\
\hline Silica gel & 0.134 & 39.2 \\
\hline Macro-Prep 50S & 0.201 & 8.09 \\
\hline Streamline SP & 0.338 & 4.16 \\
\hline Spherosil LS & 0.107 & 3.34 \\
\hline $\begin{array}{l}\text { concentration of } \\
(\mathrm{mg} / \mathrm{mg}) \text {, in equili } \\
\text { in the liquid phas } \\
\text { adsorption capaci }\end{array}$ & $\begin{array}{l}\text { ute in the adso } \\
\text { um with } C_{e q} \text {, th } \\
\mathrm{ng} / \mathrm{l}) \text {, and } \chi_{\max } \\
\text { in solute-free } b\end{array}$ & $\begin{array}{l}\text { where } \chi_{\text {eq }} \text { is the } \\
\text { ent, in solute-free basis } \\
\text { concentration of solute } \\
\text { the maximum } \\
\text { is }(\mathrm{mg} / \mathrm{mg}) \text {. }\end{array}$ \\
\hline
\end{tabular}


ty reduction of bentonite subjected to the heat treatment: it does not swell and therefore active sites inside the pores are not available to the protein molecules.

To establish this fact, the swelling capacity was restored by a treatment with $\mathrm{Na}_{2} \mathrm{CO}_{3}$ or methanol. This treatment consisted simply in placing the adsorbents in a saturated solution of either $\mathrm{Na}_{2} \mathrm{CO}_{3}$ or methanol with constant agitation for 3 days. The saturated solutions were prepared by dissolving the active agent in $500 \mathrm{~mL}$ of distilled water until saturation was observed and subsequent filtration/decantation. Both treatments were effective in restoring the swelling capacity of the clays: samples showed similar isotherms to the normal, untreated, sodium bentonite. Therefore, the swelling and the adsorption capacity are closely related.

\section{Conclusions}

The ion-exchange resins Macro-prep ${ }^{\circledR}$ 50S, SSpherosil ${ }^{\circledR}$ LS and Streamline ${ }^{\mathrm{TM}}$ SP have been shown to be potentially useful for developing a percolated bed protein adsorption system. These materials have favourable, Langmuir-type isotherms and might be used in packed or fluidized beds, although their protein adsorption capacity is lower than sodium bentonite.

The shape of the adsorption isotherms and their interpretation indicates that the adsorption characteristics of the clays are linked strongly to their swelling ability. Swelling clays and silica gel also have favourable isotherms. However, their use in percolated beds is not feasible due to their small and non-uniform particle size and aggregative properties.

\section{References}

Bayley, F.C. \& Berg, H.W. (1967). Grape and wine proteins of white wine varietals. American Journal of Enology and Viticulture, 17, 18-32.

Blade, W.H. \& Boulton, R. (1988). Adsorption of protein by bentonite in a model wine solution. American Journal of Enology and Viticulture, 39, 193-199.
Boulton, R. (1980). The nature of wine proteins. In: Proceedings of the 6th Annual Wine Industry Technology Seminar of the Wine Institute, San Francisco. Pp. 46-58.

Couture, R.A. (1985). Steam rapidly reduces the swelling capacity of bentonite. Nature, 318, 50-52.

Grim, R.E. (1939). Relation of the composition to the properties of clays. Journal of the American Ceramics Society, 22, 141-151.

Hendricks, S.B. (1942). Lattice structure of clay minerals and some properties of clays. Journal of Geology, 50, 276-290.

Hsu, J.C. \& Heatherbell, D.A. (1987). Isolation and characterization of soluble proteins in grapes, grape juice and wine. American Journal of Enology and Viticulture, 38, 6-10.

Kean, C.E. \& Marsh, G.L. (1956). Investigation of copper complexes causing cloudiness in wine. I - Chemical composition. American Journal of Enology and Viticulture, 8, 80-86.

Lamikanra, O. \& Inyang, I.D. (1988). Temperature influence on muscadine wine protein characteristics. American Journal of Enology and Viticulture, 39, 113-116.

Lehninger, A.L. (1981). Biochemistry. 2nd edn. P. 157. New York: Worth Publishers, Inc.

Loomis, W.D. (1979). Adsorbent polystyrene as an aid in plant enzyme isolation. Phytochemistry, 18, 1049-1054.

Mesrob, B., Gorinova, N. \& Tsakov, D. (1983). Characterization of the electrical properties and molecular weights of the proteins in white wines. Nahrung., 27, 727-733.

Moio, L. \& Addeo, F. (1989). Focalizzazione isoelettrica delle proteine dei mosti i dei vinie. Vignevini, 4, 53-57.

Moretti, R.H. \& Berg, H.W. (1965). Variability among wines to protein clouding. American Journal of Enology and Viticulture, 16, 69-78.

Murphey, J.M., Spayd, S.E. \& Bewers, J.R. (1989). Effect of grape maturation on soluble protein characteristics of Gewurztraminer and white Riesling juice and wine. American Journal of Enology and Viticulture, 40, 99-207.

Siddiqui, M.K.H. (1968). Bleaching Earths. P. 10. New York: Pergamon Press.

Somers, T.C. \& Ziemelis, G. (1973). Direct determination of wine proteins. American Journal of Enology and Viticulture, 24, 47-50.

Terence, A. (1990). Particle Size Measurement. 4th edn. P. 553. USA: Chapman \& Hall.

Yokotsuka, K., Yoshii, M., Aihara, T. \& Kushida, T. (1983). Turbidity formation caused by the interaction of must proteins with wine tannins. Journal of Fermentation Technology, 61, 413-416. 